\title{
Terrestrial Liming As a Restoration Technique for Acidified Forest Ecosystems
}

\author{
Sarah E. Pabian, ${ }^{1,2}$ Shawn M. Rummel, ${ }^{1}$ William E. Sharpe, ${ }^{1}$ and Margaret C. Brittingham ${ }^{1}$ \\ ${ }^{1}$ School of Forest Resources, The Pennsylvania State University, University Park, PA 16802, USA \\ ${ }^{2}$ Department of Biology, Colorado State University, Campus Delivery 1878, Fort Collins, CO 80523, USA
}

Correspondence should be addressed to Sarah E. Pabian, sarah.pabian@colostate.edu

Received 1 September 2011; Revised 4 November 2011; Accepted 7 November 2011

Academic Editor: Kristiina Vogt

Copyright (C) 2012 Sarah E. Pabian et al. This is an open access article distributed under the Creative Commons Attribution License, which permits unrestricted use, distribution, and reproduction in any medium, provided the original work is properly cited.

\begin{abstract}
We studied the effects of liming on soils and forest songbirds as well as vegetation and calcium-rich invertebrate prey variables that were predicted to link birds to changes in soil conditions. We observed increases in soil $\mathrm{pH}$, calcium, and magnesium, as well as in songbird abundances in response to lime application, with continuing increases through five years after liming. We observed an overall increase in snail abundance on limed sites, but an initial peak of a 23 fold increase three years after liming was reduced to an 11 fold increase five years after liming. We observed an increase in forb ground cover on limed sites, but liming had no effect on millipede abundance or other vegetation measures. Of the variables we measured, snail abundance was the most likely mechanism for the response in bird abundances. Because we observed continued benefits of liming up to five years post treatment, we concluded that liming is a very promising technique for restoring forest ecosystems impacted by acidic deposition.
\end{abstract}

\section{Introduction}

Anthropogenic acidic deposition, as well as forest harvesting and aging, has depleted forest soils of calcium and other nutrients and made them more acidic [1-4]. In Pennsylvania, an area that receives very high levels of acidic deposition, forest soils have experienced significant declines in soil $\mathrm{pH}$, calcium, and magnesium over the past 40 years [5]. This soil acidification and concurrent depletion of base cations, especially calcium, and increases in availability of toxic metals have the potential to negatively affect the entire forest ecosystems. Acidic deposition and soil acidification have been linked to changes in many levels of the forest ecosystem, including tree diebacks, suppressed tree regeneration, fish mortality, reduced snail abundances, and reduced avian reproductive success $[2,6]$.

One method used to mitigate the effects of acidic deposition on forest soils is to apply limestone sand. This technique was traditionally used in acidified agricultural areas, and was later applied as a mitigation technique to restore acidified bodies of water $[7,8]$. Only in the past decades has liming been used to restore acidified forests, and most of the research has taken place in Europe. Researchers have found many positive results of liming on soils, forest vegetation health and regeneration, and snail abundances [9-14]. However, very little is known about how liming affects terrestrial vertebrates, and most evaluations of the effectiveness of liming are focused on soil and water quality. An approach that includes multiple ecosystem levels would give a more complete picture of the forest ecosystem response to liming.

As a part of a larger project to restore an acidified stream to historic water-quality levels in central Pennsylvania, two, 100 ha subwatersheds were limed [15]. The primary goal of the project was to improve stream water quality, but secondary goals included revitalizing forest health and improving forest habitat for wildlife. Liming was completed using methods and materials that are available to land managers, including using a modified log skidder to spread the lime and using dolomitic limestone sand.

We focused our evaluation of the liming project on terrestrial ecosystems, from soils to terrestrial vertebrates. We selected songbirds as our focal vertebrate group because they may be particularly sensitive to soil acidification [6]. We then focused our efforts on links between soils and 
birds, including food and habitat variables. Birds require large amounts of calcium to reproduce, which is less available in acidified soils [6]. Therefore, we focused on calciumrich invertebrates, including snails and millipedes, because both contain higher levels of calcium than other forest invertebrates, and are documented to be important calcium sources for songbirds $[6,16]$. We also included vegetation measurements because bird habitat quality is associated with specific vegetative characteristics required for nesting and foraging, and vegetative characteristics can change with soil acidification $[17,18]$.

In Pabian and Brittingham [19], we reported some of our preliminary findings on soil calcium, snail abundance, and songbird abundance. We observed that before liming the study sites were of poor quality for forest songbirds, as measured by a low abundance of birds and large territory size of our focal species. Liming resulted in increased songbird abundances and increased territory density. However, our findings were somewhat inconclusive and incomplete because we did not have enough information to observe effects of liming on individual bird species, and we did not evaluate the effects of liming on many important soil, invertebrate, and vegetation variables. To give a more complete picture of the effects of liming on forest ecosystems and to better evaluate the effectiveness of terrestrial liming for restoring acidified forests, we continued the study for an additional two years and incorporated more ecosystem variables into our analysis and report.

\section{Methods}

2.1. Study Sites. This study was conducted in the Mosquito Creek Watershed located in Clearfield, Cameron, and Elk counties in central Pennsylvania over the summers of 20032008. This study was focused on four, 100 ha watersheds (sites) in the Gifford Run drainage to Mosquito Creek in Clearfield County $\left(41^{\circ} 11^{\prime} \mathrm{N}\right.$ and $\left.78^{\circ} 17^{\prime} \mathrm{W}\right)$. For more site details, see Pabian and Brittingham [19].

2.2. Study Design. We conducted this study over a six-year period (2003-2008) using a Before-After-Control-Impact (BACI) study design [20]. The BACI design controls for natural environmental variation that affects all sites and controls for any initial site differences [21]. During year one, we collected data at all four sites before liming. Before the beginning of the bird-breeding season in year two, we randomly selected two of the four sites and applied approximately $4500 \mathrm{~kg} / \mathrm{ha}$ of dolomitic limestone sand using a modified log skidder. For more liming details see Pabian and Brittingham [19]. We collected data on the limed and control sites over the following three years and again in the fifth year after liming. Preliming conditions and some of the results through 2006 have been published, so this paper will focus on what was not covered in that paper [19]. Within each of the four sites, we established 17 survey points per site (68 points total) for bird point counts, invertebrate counts, soil samples, and vegetation measurements. The points were located $200 \mathrm{~m}$ apart on a grid.
2.3. Soils. We collected Oa-horizon soil samples at the 68 survey points in all years. We collected soils in 2003, 2004, 2006, and 2008 during the first two weeks in July, and collected soils in 2005 during the last week in May. Soils were analyzed at the Pennsylvania State University Agricultural Analytical Services Lab for exchangeable calcium (Ca), magnesium $(\mathrm{Mg})$, potassium $(\mathrm{K})$, and phosphorus $(\mathrm{P})$ using the Mehlich 3 (ICP) method [22] and $\mathrm{pH}$ in water paste [23]. In 2003-2006, we additionally analyzed soil samples for plant available aluminum and calcium in the A-horizon using a $0.01 \mathrm{M} \mathrm{SrCl}_{2}$ saturated paste extract to calculate the calcium to aluminum ratio.

2.4. Snails and Millipedes. We sampled both snails and millipedes at the survey points using timed-area searches centered at each of the 68 survey points each year. Plot locations were shifted each year to avoid resampling the same areas. We completed all surveys between the last week in June and second week in July. Snails and millipedes were surveyed by hand searching the leaf litter, down to the Oa-horizon, in a $25 \mathrm{~m}^{2}$ area for 20 minutes [24-26]. Searches were completed between 0700 and 1200 hours on days without rain 24 hours prior to searching.

2.5. Vegetation. We quantified vegetation at each of the 68 survey points using methods from Martin et al. [27]. We measured vegetation from the last week in June through the second week in August. We measured vegetation within four plots located within a $50 \mathrm{~m}$ radius of each survey point. Each survey plot had a $5 \mathrm{~m}$ radius, for counting shrubs and saplings. We counted all shrubs and saplings by species, estimated ground cover of forbs, ferns, shrubs, and grass, and measured leaf litter depth within $5 \mathrm{~m}$ radius plots, and we measured canopy cover from the center of each plot. Leaf litter depth was measured by using hard plastic rulers with no boarders to dig small holes to where individual leaf parts were no longer visible. We used a spherical crown densiometer to take four measurements (in each cardinal direction) of canopy cover from the center of each plot. Vegetation measurements were made in 2003, 2004, 2005, and 2008. We used the means from the four vegetation plots at each survey point in our data analysis.

2.6. Bird Abundance. We monitored bird abundance using point counts at the 68 survey points every year. The points were separated by $200 \mathrm{~m}$ to prevent repeat counts of the same birds [27]. Upon arrival at a survey point, we waited one minute before beginning the count. We recorded any bird seen or heard for $5 \mathrm{~min}$. within a $50 \mathrm{~m}$ fixed-radius circle. Each year, we completed point counts three times at each site between 1 June and 15 July. To avoid any time-of-day effects, we surveyed points in different orders each time. We conducted surveys between 0600 and 1000 on days without strong wind, rain, or dense fog. We used the maximum number of each species recorded from the three surveys completed each year for each point for analysis.

2.7. Analysis. All statistical analyses were completed in $\mathrm{R}$ [28]. We used mixed-effects models to conduct repeated 
measures generalized linear models on the data collected at the point level for soils, invertebrates, vegetation, and bird abundances. We used the lmer function from the lme4 package to analyze the data [29]. The models included fixed treatment and time effects, fixed treatment by time interaction effect, random site effect, and random point within site effect. Random effects allowed us to structure the error to account for repeated samples within sites and repeated measures over time without committing pseudoreplication [30]. We used the time by treatment interaction to evaluate the effect of liming, which evaluates if the limed sites changed differently than the control sites from before liming to after.

We log-transformed most count and soil variables to make them approximately normal, and we arcsinetransformed all percentages. If any visual examination of data indicated a peak, we modeled it with a quadratic term for time, and used the ANOVA function in $\mathrm{R}$ to perform a drop in deviance $\chi$-squared test to determine if the quadratic term improved the model [28].

We assessed the magnitude and uncertainty in the time by treatment interaction parameter estimates using $95 \%$ confidence limits generated using Markov Chain Monte Carlo (MCMC) samples from the posterior distribution of each parameter estimate using the mcmcsamp function in the R package lme4 [29] and computing the Bayesian highest posterior density (HPD) 95\% confidence limits of the MCMC samples using the HPDinterval function in the $\mathrm{R}$ package coda [31]. We considered confidence limits that excluded zero to indicate a time-by-treatment interaction and an effect of liming on the variable measured. We reported interaction effect parameter estimates with their confidence intervals (CIs) and the changes that occurred on control and treatment sites with their standard errors to indicate the direction and magnitude of the liming effect.

For bird abundance data, we divided the songbirds into three foraging categories: ground-, understory-, and canopy-foraging species. Because the lime was applied to the ground, we predicted the invertebrates on the ground and the understory vegetation would be affected first and thus the ground-foraging birds would be the first to respond to liming. Ground-foraging birds included veery (Catharus fuscescens), hermit thrush (C. guttatus), ovenbird (Seiurus aurocapilla), common yellowthroat (Geothlypis trichas), eastern towhee (Pipilo erythrophthalmus), chipping sparrow (Spizella passerina), dark-eyed junco (Junco hyemalis), and indigo bunting (Passerina cyanea). Understory-foraging birds included blue-headed vireo (Vireo solitarius), chestnutsided warbler (Setophaga pensylvanica), black-throated blue warbler (S. caerulescens), and American redstart (Setophaga ruticilla). Canopy-foraging birds included eastern woodpewee (Contopus virens), least flycatcher (Empidonax minimus), eastern phoebe (Sayornis phoebe), red-eyed vireo (Vireo olivaceus), black-throated green warbler (S. virens), blackburnian warbler (S. fusca), scarlet tanager (Piranga olivacea), and rose-breasted grosbeak (Pheucticus ludovicianus). Classifications were based on foraging information included in the birds of North America species accounts [32].

\section{Results}

3.1. Soils. We observed increases in soil calcium, magnesium, and $\mathrm{pH}$ in response to liming (Figure 1). From the first year of the study, before liming, to five years after liming, soil exchangeable calcium did not substantially change on control sites $(1.19 \pm 1.14 \mathrm{cmol} / \mathrm{kg}$ change $)$ and increased by $8.00 \pm 1.61 \mathrm{cmol} / \mathrm{kg}$ on limed sites (a 4.1 fold increase from before liming; Figure 1). Soil exchangeable magnesium did not change on control sites $(0.61 \pm 0.39 \mathrm{cmol} / \mathrm{kg}$ change $)$ and increased by $6.76 \pm 1.10 \mathrm{cmol} / \mathrm{kg}$ on limed sites (a 5.5 fold increase from before liming; Figure 1). Soil $\mathrm{pH}$ also did not change on control sites $(0.03 \pm 0.13$ change in $\mathrm{pH})$ and increased by a mean $\mathrm{pH}$ of $0.86 \pm 0.17$ on limed sites (Figure 1). We detected no significant effect of liming on soil exchangeable potassium and phosphorus (Figure 1).

We also observed an increase in the soil calcium to aluminum ratio in response to liming (Figure 1). From 2003 to 2006, Ca:Al increased on limed sites by $2.41 \pm 1.20$ and remained the same on control sites $(0.99 \pm 1.36)$. Before liming, $66 \%$ of the survey points had Ca:Al below one, and after liming, only $24 \%$ of the points in the limed sites had Ca:Al below one.

3.2. Snails and Millipedes. We observed an increase in snail abundances and no change in millipede abundances in response to liming (Figure 2). Snail abundance peaked in 2006 and decreased in 2008; therefore, we evaluated a quadratic term in our statistical model to describe changes with time. Adding a quadratic year term to the model significantly improved the model fit to the data $\left(\chi_{2 \mathrm{df}}^{2}=42.00\right.$, $P<0.001)$. From the year before liming to three years after (when snail abundance on limed sites peaked) snail abundance did not change on control sites $(0.29 \pm 0.17$ change in snails per point) and increased by 23 fold on limed sites $(1.26 \pm 0.24$ snails per point). From the year before liming to five years after, snail abundance did not change on control sites $(0.21 \pm 0.15$ change in snails per point $)$ and increased by 11 fold on limed sites $(0.59 \pm 0.14$ change in snails per point; Figure 2).

3.3. General Vegetation. We observed an increase in forb ground cover in response to liming (Figure 3 ) and no effect of liming on the other vegetation variables we measured (Table 1). Absolute forb ground cover increased on control sites by $6.67 \pm 1.13 \%$ and increased on limed sites by $12.67 \pm$ $1.98 \%$ from before liming to five years after liming.

3.4. Bird Abundance. We counted 43 bird species over the course of the study. We observed an increase in overall bird abundance in response to liming (Figure 4). The number of birds per point did not change from before liming to five years after liming on control sites $(0.97 \pm 0.56$ change in number of birds per point) and increased by 1.88 fold on limed sites ( $3.09 \pm 0.53$ change in number of birds per point; Figure 4).

When songbirds were grouped in ground-, understory-, and canopy-foraging categories, we observed increased 

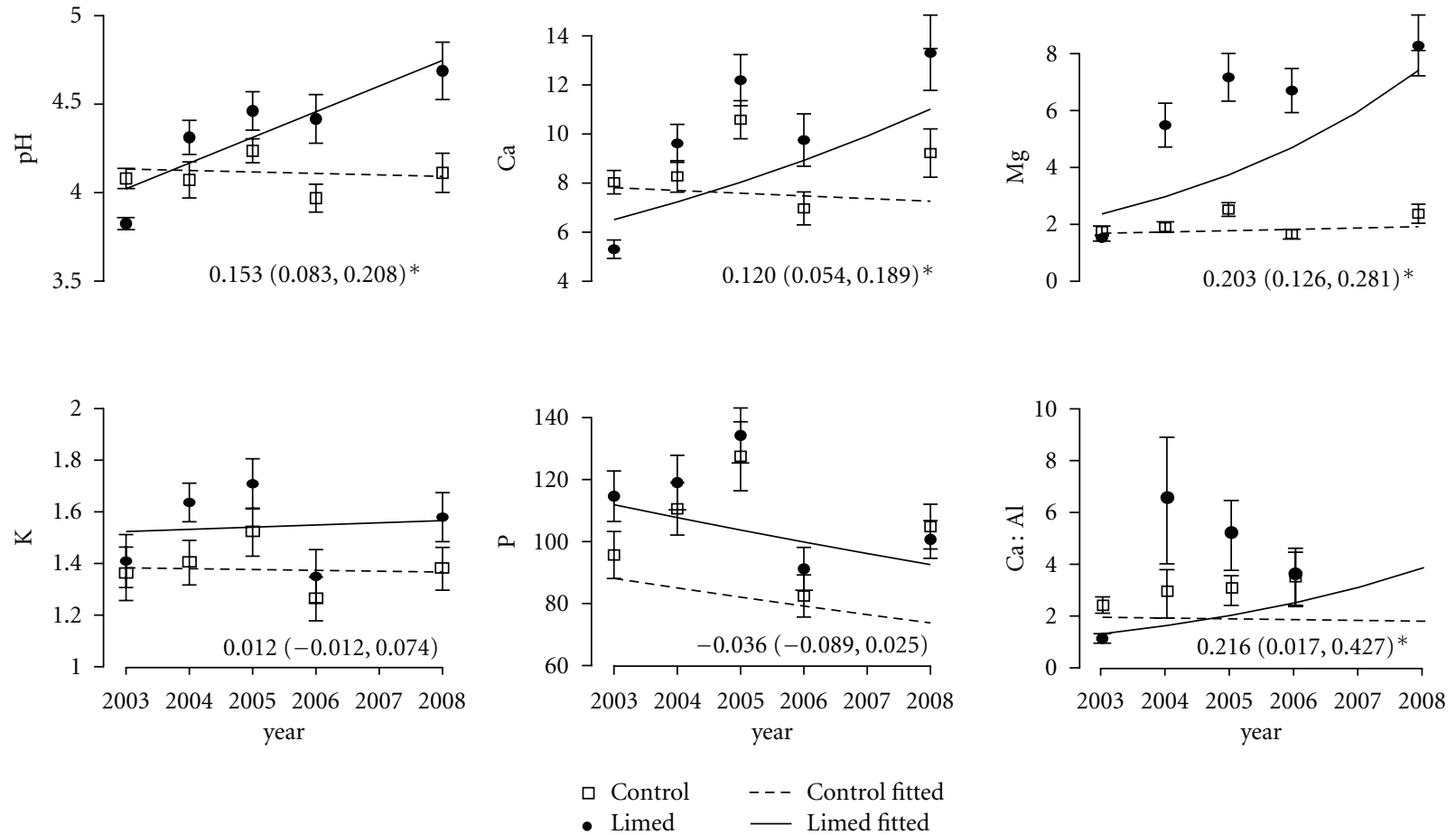

Figure 1: Mean soil pH, soil exchangeable calcium (Ca), magnesium (Mg), potassium (K), and phosphorus (P) in $\mathrm{cmol} / \mathrm{kg}$ and soil Ca:Al ratio with SE bars on lime-treated and control sites with model lines. Lime treatment was applied between 2003 and 2004 in central Pennsylvania. ${ }^{*}$ Confidence intervals of the time-by-treatment interaction excluded zero, indicating a significant effect of liming on that variable.

TABLE 1: Effect of liming on vegetation, with parameter estimates for the year-treatment interactions with $95 \%$ highest posterior density (HPD) intervals from Markov Chain Monte Carlo samples from repeated measures analysis of data collected in PA before and after lime application on two of four forest sites. All of the confidence intervals (CIs) include zero, indicating no significant effect of liming on those variables.

\begin{tabular}{lccccc}
\hline & \multicolumn{2}{c}{ Control } & \multicolumn{2}{c}{ Limed } & Interaction $(\mathrm{CIs})$ \\
& $2003(\mathrm{SE})$ & $2008(\mathrm{SE})$ & $2003(\mathrm{SE})$ & $2008(\mathrm{SE})$ & $-0.017(-0.043,0.008)$ \\
\hline Litter depth $(\mathrm{mm})$ & $20.94(0.81)$ & $27.50(0.71)$ & $22.78(1.15)$ & $27.07(0.90)$ & $-0.002(-0.013,0.008)$ \\
Canopy cover $(\%)$ & $85.78(1.30)$ & $91.88(1.18)$ & $85.60(1.82)$ & $91.15(1.32)$ & $0.115(-0.014,0.252)$ \\
Sapling density (count/site) & $897(8)$ & $1161(6)$ & $297(8)$ & $587(5)$ & $-0.007(-0.227,0.214)$ \\
Shrub density (count/site) & $602(9)$ & $851(9)$ & $1447(9)$ & $2073(12)$ & $0.013(-0.008,0.036)$ \\
Grass cover $(\%)$ & $9.17(2.09)$ & $3.90(1.38)$ & $6.71(1.47)$ & $3.81(0.86)$ & $-0.028(-0.066,0.009)$ \\
Fern cover $(\%)$ & $51.54(4.69)$ & $55.75(4.97)$ & $39.10(4.19)$ & $31.54(3.86)$ & $0.027(-0.009,0.062)$ \\
Shrub cover $(\%)$ & $17.98(3.15)$ & $25.67(3.65)$ & $28.13(4.15)$ & $49.66(3.96)$ & \\
\hline
\end{tabular}

abundances of ground- and understory-foraging bird abundances in response to liming, but no change in canopyforaging bird abundances (Figure 4). Ground-foraging songbird abundance, from before liming to five years after liming, did not change on control sites $(0.24 \pm 0.32$ change in birds per point) and increased by 2.6 fold on limed sites ( $1.50 \pm$ 0.26 change in birds per point; Figure 4). Ground-foraging bird species that most strongly followed this pattern were ovenbird, veery, and eastern towhee. Ovenbird abundance did not change on control sites from before liming to five years after liming $(0.18 \pm 0.13$ change in abundance $)$ and increased on limed sites $(0.56 \pm 0.13$ change in abundance; Figure 5). Veery abundance had a decreasing trend on control sites $(-0.12 \pm 0.07$ change in abundance) and increased on limed sites $(0.21 \pm 0.09$ change in abundance; Figure 5). Eastern towhee abundance did not change on control sites $(-0.09 \pm 0.13$ change in abundance $)$ and increased on limed sites $(0.26 \pm 0.12$ change in abundance; Figure 5). Understory-foraging songbird abundance, from before liming to five years after liming, did not change on control sites $(0.235 \pm 0.224$ change in birds per point $)$ and increased on limed sites $(0.706 \pm 0.217$ change in birds per point; Figure 4). The chestnut-sided warbler followed the same trend and did not change on control sites $(-0.029 \pm$ 0.075 change in birds per point) and increased on limed sites $(0.324 \pm 0.123$ change in birds per point; Figure 5$)$. 

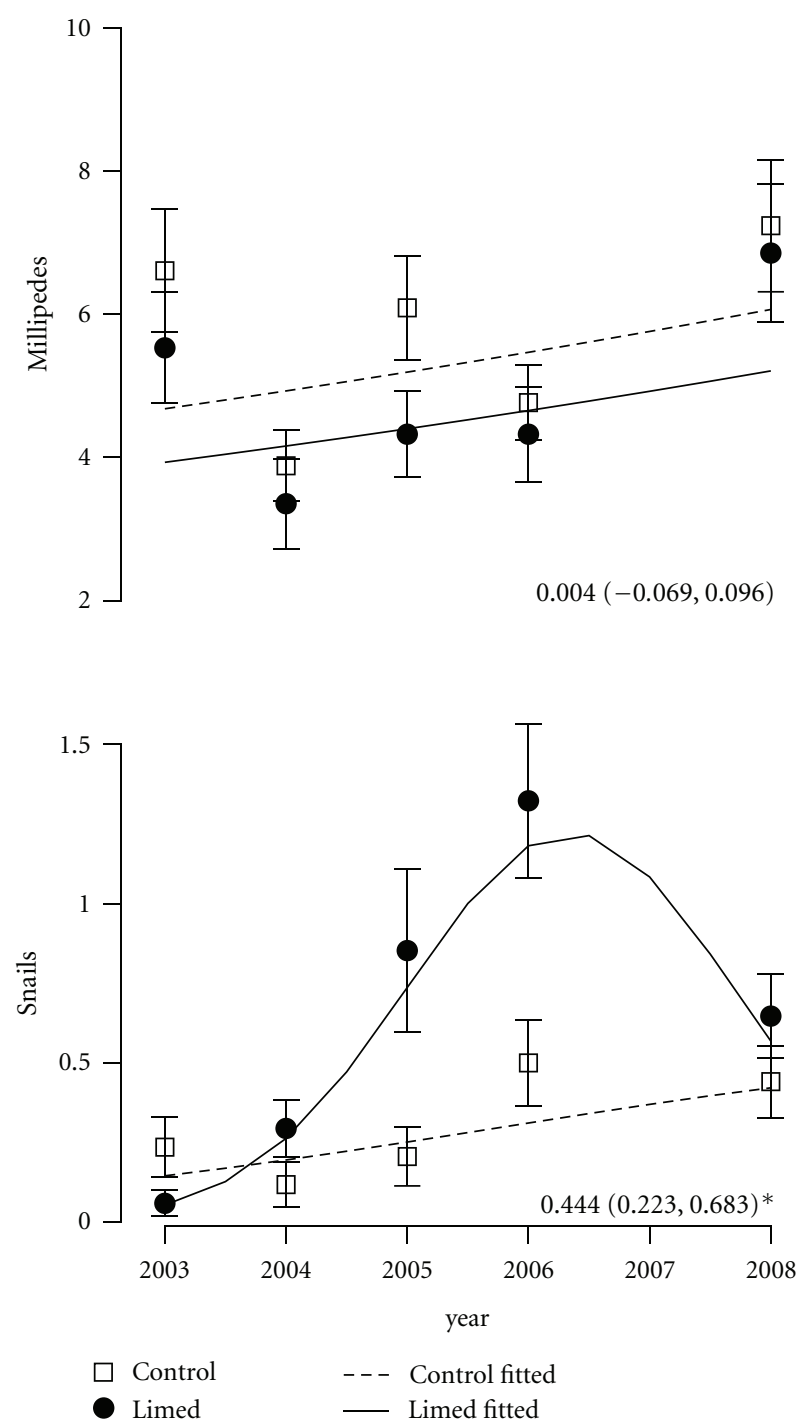

FIGURE 2: Mean millipede and snail abundance (number per $25 \mathrm{~m}^{2}$ ) with SE bars on lime-treated and control sites with model lines. Lime treatment was applied between 2003 and 2004 in central Pennsylvania. * Confidence intervals of the time-by-treatment interaction excluded zero, indicating a significant effect of liming on that variable.

\section{Discussion}

We observed beneficial effects of liming at multiple ecosystem levels five years after lime was applied to study areas within and acidified forest and gained a better understanding of the links between soil conditions and other components of the forest ecosystem. With data from an additional two years after liming since our preliminary report [19], we continued to observe increases in soil $\mathrm{pH}$, calcium availability, and bird abundance. We also observed unexpected results, with snail abundance initially increasing and then decreasing, although still remaining significantly more abundant than prior to liming. Some components of the forest ecosystem (e.g., millipede abundance and vegetation) did not respond or responded too slowly to liming to be observed in five

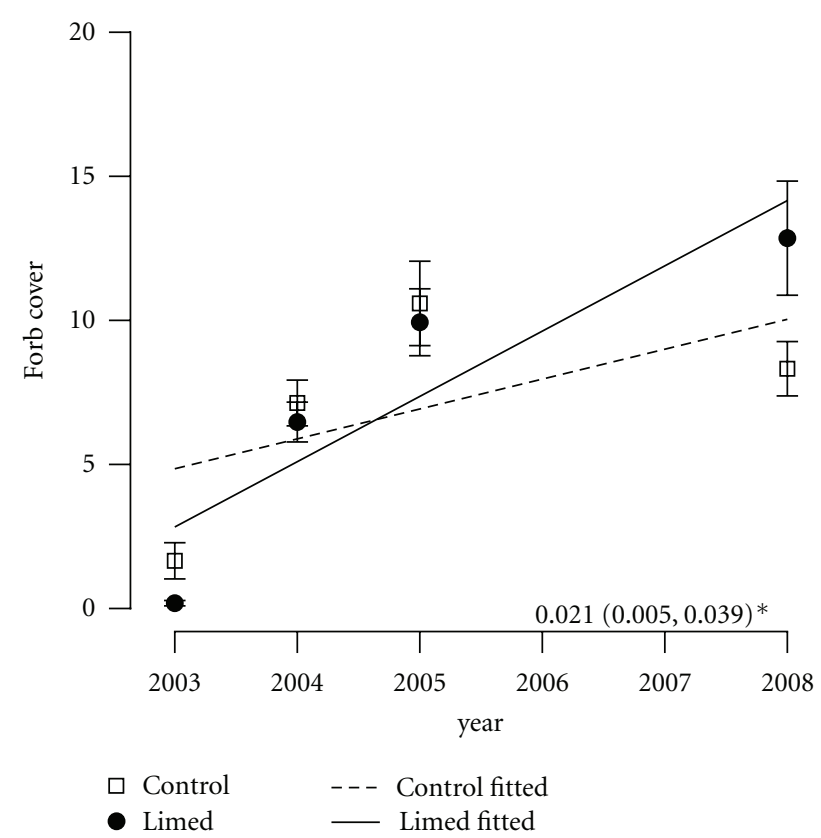

FIGURE 3: Mean percent understory coverage of forbs with SE bars and model lines on lime-treated and control sites. Lime treatment was applied between 2003 and 2004 in central Pennsylvania. * Confidence intervals of the time-by-treatment interaction excluded zero, indicating a significant effect of liming on that variable.

years. These combined responses to liming indicate a strong bottom-up influence of soil nutrients in an acidified forest and a link between soil conditions and songbird abundance.

4.1. Soils. The continued increases observed in soil $\mathrm{pH}$, calcium, and magnesium five years after liming are promising and agree with other liming studies that one application of lime can continue to improve and maintain improved soil condition for a long time. In other studies, continued increases in these soil parameters have been observed beyond five years after dolomitic limestone application [10]. Also, based on models, dolomitic lime application is predicted to elevate soil-base cation levels for up to 50 years, with continued increases in the first 15 to 20 years, followed by a gradual decline [12]. The increases in soil $\mathrm{pH}$ brought average soil condition from below 4.0, which is considered too low to maintain healthy oak forests, to 4.7 and never exceeded normal soil conditions for forest soils in the area (no soils with $\mathrm{pH}>7.0$ ) [33]. Potential negative effects of liming on soils include decreases in potassium, resulting from displacement by $\mathrm{Mg}$ and $\mathrm{Ca}$, and decreased phosphorus, resulting from the formation of insoluble Ca phosphates or uptake by plants [34-36]. Unlike in other liming studies, we observed no substantial effects of dolomitic lime application on soil P or K [10, 37].

Soil calcium/aluminum ratios below one are related to a high risk of adverse tree growth or nutrition [38]. Before liming, we observed ratios as low as 0.35 , and the majority of soil samples were below one. After liming, many soil samples remained below one, but the majority became above one, 

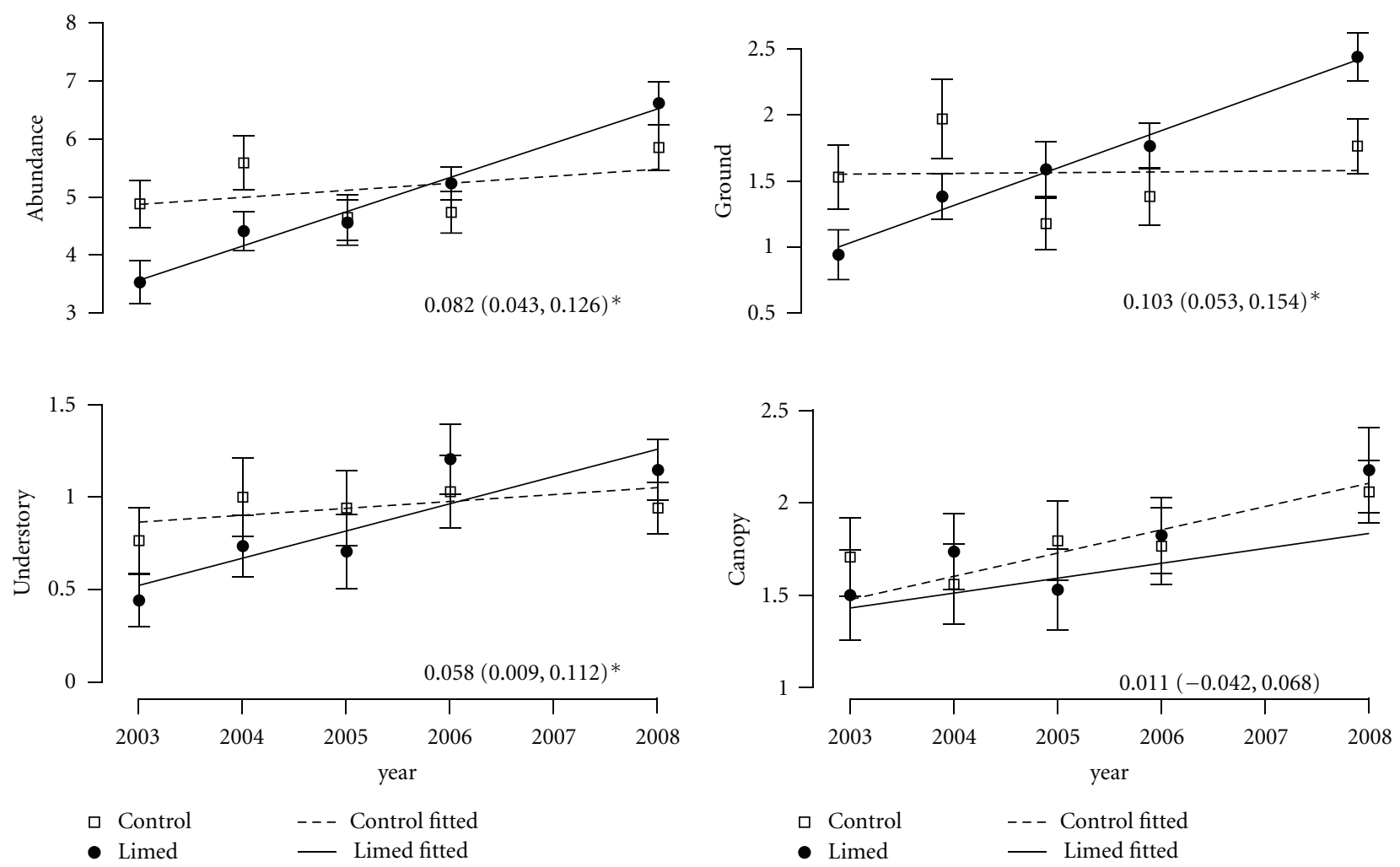

Figure 4: Mean number of all birds (abundance) and of ground-, understory-, and canopy-foraging birds (birds per point) with SE bars and model lines on lime-treated and control sites. Lime treatment was applied between 2003 and 2004 in central Pennsylvania. *Confidence intervals of the time-by-treatment interaction excluded zero, indicating a significant effect of liming on that variable.

indicating substantial improvement of soil conditions for tree health.

4.2. Invertebrates. Although both snails and millipedes contain high levels of calcium, only snail abundances increased after liming. Snail abundances peaked three years after liming with a 23 fold increase, then unexpectedly decreased. Despite a 50\% decline in snail abundance during the fourth and fifth years of the study, snail abundance was still 11 times higher on limed sites than before liming. The decline in snail abundance was unlikely a result of diminishing effects of lime application. We observed increases and elevated levels of calcium and $\mathrm{pH}$ in the soils five years after liming, and the effects of liming are predicted to last much longer [12]. Birds may play a large role in trophic cascades and have great potential to control populations of invertebrate prey items $[39,40]$ and, potentially, the increase in bird abundance in response to liming resulted in an increased rate of snail predation, especially if snails are indeed a critical calcium source in the study area. Other factors unrelated to liming, such as soil and litter moisture, can also affect snail abundances [41] however; we did not record any differences in litter moisture in the final year compared to other years or control sites.

We also analyzed the effects of liming on millipedes because they are a potential source of calcium for breeding songbirds [16]. Contrary to our prediction, millipede abundance did not respond to liming. Although millipedes contain relatively high amounts of calcium, their abundances seem more sensitive to leaf litter depth and moisture, and in other research, we found that abundances were negatively related to soil $\mathrm{pH}$ [42]. Researchers in the past have observed mixed results when investigated the relationship between diplopods and soil conditions. Kalisz and Powell [43] observed higher millipede biomass on soils with higher soil calcium and $\mathrm{pH}$ resulting from proximity to limestone roads, while Wasson [44] found a strong negative trend between millipede abundance and soil calcium availability. Because millipede abundances did not increase after liming, we believe that they were not limited by soil $\mathrm{pH}$ or calcium levels.

4.3. Vegetation. We observed very little evidence that liming had any large effects on vegetation structure. Potentially, subtle changes in canopy cover and understory vegetation could have occurred, which our methods were not designed to detect. However, our methods did a sufficient job measuring the potential for larger changes that would affect bird habitat quality.

The only vegetation response to liming was an increase in forb cover. In other research, we looked more closely at the response of understory vegetation biomass to liming and also only found a positive response of forb biomass to liming, similar to these results [42]. 

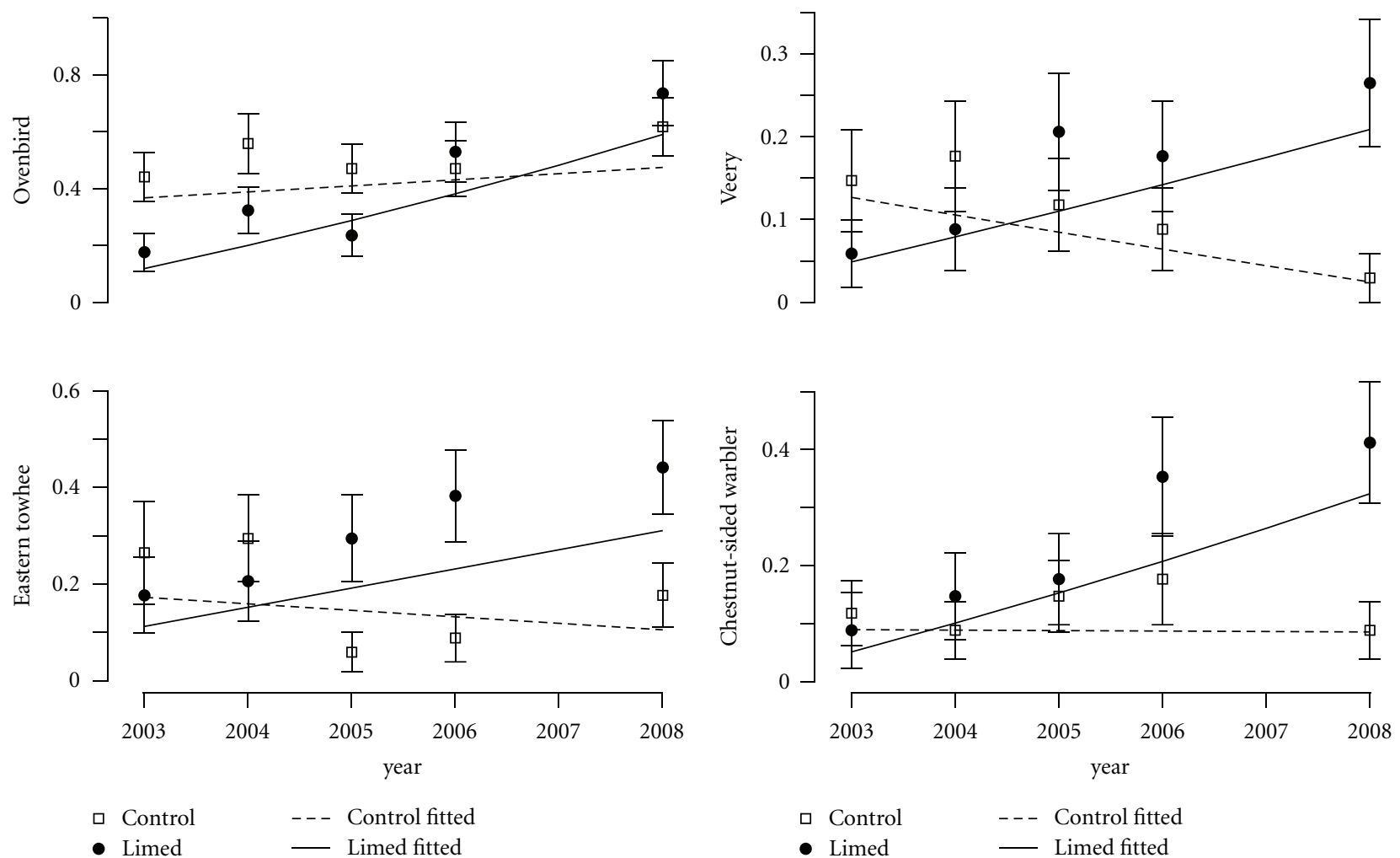

Figure 5: Mean abundance (count per point) of Ovenbird, Veery, Eastern Towhee, and Chestnut-sided Warbler with SE bars and model lines on lime-treated and control sites. Lime treatment was applied between 2003 and 2004 in central Pennsylvania.

We expected the greatest changes in vegetation to occur in canopy cover, leaf litter depth, understory vegetation cover, and sapling density. We predicted increased canopy cover after liming because other researchers found increases in canopy health and cover after liming $[9,13,14]$; however, these studies focused on declining sugar maple stands, and we found no evidence of diebacks or decline in the trees in our study, nor did we have any sugar maples on our study sites. We predicted that understory vegetation would respond to liming; however, other potentially limiting factors, such as light, competition with hay-scented fern, or other nutrients could have prevented a response to liming [45]. Many researchers observed positive responses of mature tree basal area growth to liming, but our methods would not have been able to detect such changes $[9,10,13]$. However, Donaldson [46] measured radial growth of trees at the same study sites and found only a slight increasing trend in growth after liming.

4.4. Bird Abundance. We continued to observe increases in bird abundance through five years after liming, with nearly double the number of birds per point count since the year before liming. The increase in abundance between years was also fairly constant, with an average increase of 0.6 birds per point per year. With the additional two years, we were able to support our hypothesis that groundand understory-foraging birds would benefit more than canopy-foraging birds. We were also able to detect positive effects of liming on individual species, and no species declined in abundance after liming. Many of the species that benefited from liming, such as veery, chestnut-sided warbler, American redstart, common yellowthroat, eastern towhee, and indigo bunting are currently declining either regionally or nationally [47], suggesting that this technique could be beneficial for restoring bird populations at least locally.

We predicted that forest songbirds could respond to changes in soil conditions caused by liming through vegetation changes or changes in invertebrate prey availability. Because we observed little change in vegetation structure, we strongly suspect that increased calcium availability in snails was the most likely mechanism (of the variables we measured) for increases in bird abundance. Snails are an important calcium source for many forest songbirds because they store little to no calcium for reproduction and their diets do not normally contain enough $[6,48,49]$. By increasing snails for great tits (Parus major), Graveland et al. [6] reduced the occurrence of thin eggshells that were common in birds breeding in highly acidified areas. Increased calciumrich prey availability could improve reproductive output, potentially resulting in higher return rates of adults and more young birds returning to the same area to reproduce. In addition, snails could be a strong indicator of habitat quality and increase immigration rates. Because snail abundances were reduced in the final year of the study, bird abundances could also eventually decrease, but continued data collection would be required to examine this possibility. 
We also recognize that changes in other invertebrate species, which we did not measure, could also be responsible for increases in bird abundances, but in past liming studies, snails have been the only invertebrate to regularly benefit from base cation additions, with mixed results in other invertebrate groups [50-53]. Liming has been shown to increase earthworm abundances, but earthworms were not present at our study sites [54]. Caterpillars are a major food source for many forest songbirds, but no studies have found changes in caterpillar abundances with liming, as most liming studies have focused on aquatic or litter invertebrates [51-53, 55]. However, Haack [56] observed greater caterpillar abundances in more acidified areas, likely resulting from increased palatability of tree foliage when trees were under mild-to-moderate pollution stress from acidic deposition, and Butler [57] observed higher abundances of caterpillars in an experimentally acidified site compared to control.

4.5. Evaluation. Use of the BACI study design helped overcome problems associated with natural environmental variability in field experiments. Because the BACI analysis tests the change in a variable from before to after treatment, any initial differences in conditions are controlled for. The BACI design also helps control for environmental factors that affected all of the study sites. For example, we observed increases in forb ground cover on both control and limed sites from before to after liming, indicating that an environmental factor common to all four study sites was responsible. Using the BACI design, we were able to detect an effect of liming on forb cover because the change was much greater on limed sites compared to control sites.

Terrestrial application of dolomitic limestone sand was successful at improving soil condition to the point of being near preacidic deposition levels. The change in soil conditions benefited snail and songbird abundances, including bird species with declining populations, but did not have much affect of forest vegetation. Combining these successes with the successful improvement in water conditions [15], liming may be a very economical option for forest quality improvement and restoration in areas impacted by acidic deposition. Lime application using dolomitic limestone sand and a modified skidder resulted in costs less than $\$ 100$ per ha, making it a feasible option for land managers.

\section{Acknowledgments}

The authors thank D. Becker, D. Behrend, S. Chiavacci, N. Cohen, C. Coverstone, N. Ermer, D. Grear, J. Kauffman, T. Keller, K. Lynott, N. Mizel, G. Stokke, E. Stuber, C. Voorhees, and T. Weidman for assistance in the field. Funding was provided by Pennsylvania DCNR Wild Resource Conservation Program and the Pennsylvania State University Agriculture Research Station. This research was part of a larger project evaluating whole watershed liming funded by the Pennsylvania Department of Environmental Protection through an Environmental Stewardship and Watershed Protection Grant to Pennsylvania State University. Use of field sites was permitted by the Pennsylvania Department of
Conservation and Natural Resources and the Pennsylvania Game Commission.

\section{References}

[1] M. B. Adams, J. A. Burger, A. B. Jenkins, and L. Zelazny, "Impact of harvesting and atmospheric pollution on nutrient depletion of eastern US hardwood forests," Forest Ecology and Management, vol. 138, no. 1-3, pp. 301-319, 2000.

[2] C. T. Driscoll, G. B. Lawrence, A. J. Bulger et al., "Acidic deposition in the northeastern United States: sources and inputs, ecosystem effects, and management strategies," BioScience, vol. 51, no. 3, pp. 180-198, 2001.

[3] S. P. Hamburg, R. D. Yanai, M. A. Arthur, J. D. Blum, and T. G. Siccama, "Biotic control of calcium cycling in Northern Hardwood forests: acid rain and aging forests," Ecosystems, vol. 6, no. 4, pp. 399-406, 2003.

[4] R. A. F. Warby, C. E. Johnson, and C. T. Driscoll, "Continuing acidification of organic soils across the northeastern USA: 1984-2001," Soil Science Society of America Journal, vol. 73, no. 1, pp. 274-284, 2009.

[5] S. W. Bailey, S. B. Horsley, and R. P. Long, "Thirty years of change in forest soils of the Allegheny Plateau, Pennsylvania," Soil Science Society of America Journal, vol. 69, no. 3, pp. 681690, 2005.

[6] J. Graveland, R. Van Der Wal, J. H. Van Balen, and A. J. Van Noordwijk, "Poor reproduction in forest passerines from decline of snail abundance on acidified soils," Nature, vol. 368, no. 6470, pp. 446-448, 1994.

[7] T. S. Traaen, T. Frogner, A. Hindar, E. Kleiven, A. Lande, and R. F. Wright, "Whole-catchment liming at Tjonnstrond, Norway: an 11-year record," Water, Air, and Soil Pollution, vol. 94, no. 1-2, pp. 163-180, 1997.

[8] J. Gunn, R. Sein, B. Keller, and P. Beckett, "Liming of acid and metal contaminated catchments for the improvements for the improvement of drainage water quality," Water, Air, and Soil Pollution, vol. 130, no. 1-4, pp. 1439-1444, 2001.

[9] T. R. Wilmot, D. S. Ellsworth, and M. T. Tyree, "Base cation fertilization and liming effects on nutrition and growth of Vermont sugar maple stands," Forest Ecology and Management, vol. 84, no. 1-3, pp. 123-134, 1996.

[10] R. P. Long, S. B. Horsley, and P. R. Lilja, "Impact of forest liming on growth and crown vigor of sugar maple and associated hardwoods," Canadian Journal of Forest Research, vol. 27, no. 10, pp. 1560-1573, 1997.

[11] L. E. Johannessen and T. Solhøy, "Effects of experimentally increased calcium levels in the litter on terrestrial snail populations," Pedobiologia, vol. 45, no. 3, pp. 234-242, 2001.

[12] A. Hindar, R. F. Wright, P. Nilsen, T. Larssen, and R. Høgberget, "Effects on stream water chemistry and forest vitality after whole-catchment application of dolomite to a forest ecosystem in southern Norway," Forest Ecology and Management, vol. 180, no. 1-3, pp. 509-525, 2003.

[13] J. D. Moore and R. Ouimet, "Ten-year effect of dolomitic lime on the nutrition, crown vigor, and growth of sugar maple," Canadian Journal of Forest Research, vol. 36, no. 7, pp. 18341841, 2006.

[14] S. M. Juice, T. J. Fahey, T. G. Siccama et al., "Response of sugar maple to calcium addition to northern hardwood forest," Ecology, vol. 87, no. 5, pp. 1267-1280, 2006. 
[15] W. E. Sharpe, M. C. Brittingham, W. M. Tzilkowski et al., "Evaluation of whole watershed and riparian wetland liming to mitigate acidity," Final Report Grant 41000155481ME352917, The Pennsylvania Department of Environmental Protection,, 2006.

[16] S. Bureš and K. Weidinger, "Sources and timing of calcium intake during reproduction in flycatchers," Oecologia, vol. 137, no. 4, pp. 634-647, 2003.

[17] M. Darveau, J. Martel, J. L. Desgranges, and Y. Mauffette, "Associations between forest decline and bird and insect communities in northern hardwoods," Canadian Journal of Forest Research, vol. 27, no. 6, pp. 876-882, 1997.

[18] M. L. Cody, "Habitat selection in birds: the role of vegetation structure, competitors, and productivity," BioScience, vol. 31, pp. 107-113, 1981.

[19] S. E. Pabian and M. C. Brittingham, "Terrestrial liming benefits birds in an acidified forest in the northeast," Ecological Applications, vol. 17, no. 8, pp. 2184-2194, 2007.

[20] T. L. Mcdonald, W. P. Erickson, and L. L. Mcdonald, "Analysis of count data from before-after control-impact studies," Journal of Agricultural, Biological, and Environmental Statistics, vol. 5, no. 3, pp. 262-276, 2000.

[21] E. P. Smith, "BACI design," in Encyclopedia of Environmetrics, A. H. El-Shaarawi and W. W. Piegorsch, Eds., pp. 141-148, Wiley, Chichester, UK, 2002.

[22] A. M. Wolf and D. B. Beegle, "Recommended soil tests for macronutrients: phosphorus, potassium, calcium, and magnesium," in Recommended Soil Testing Procedures for the Northeastern United States, Northeast Regional Bulletin no. 493, J. Thomas Sims and A. Wolf, Eds., pp. 25-34, Agricultural Experiment Station, University of Delaware, Newark, Del, USA, 1995.

[23] D. Eckert and J. Thomas Sims, "Recommended soil pH and lime requirement tests," in Recommended Soil Testing Procedures for the Northeastern United States, Northeast Regional Bulletin no. 493, J. Thomas Sims and A. Wolf, Eds., pp. 1116, Agricultural Experiment Station, University of Delaware, Newark, Del, USA, 1995.

[24] R. Mesibov, R. J. Taylor, and R. N. Brereton, "Relative efficiency of pitfall trapping and hand-collecting from plots for sampling of millipedes," Biodiversity and Conservation, vol. 4, no. 4, pp. 429-439, 1995.

[25] K. D. McCoy, "Sampling terrestrial gastropod communities: using estimates of species richness and diversity to compare two methods," Malacologia, vol. 41, no. 1, pp. 271-281, 1999.

[26] K. P. Hotopp, "Land snails and soil calcium in central Appalachian mountain forest," Southeastern Naturalist, vol. 1, no. 1, pp. 27-44, 2002.

[27] T. E. Martin, C. R. Paine, C. J. Conway, W. M. Hochochka, P. Allen, and W. Jenkins, BBIRD Field Protocol, Montana Cooperative Wildlife Research Unit, University of Montana, Missoula, Mont, USA, 1997.

[28] R Development Core Team, "R: a language and environment for statistical computing," R Foundation for Statistical Computing, Vienna, Austria, 2009, http://www.R-project.org.

[29] D. Bates and M. Maechler, lme4: Linear mixed-effects models using S4 classes, R package version 0.999375-31, 2009, http://CRAN.R-project.org/package=lme4.

[30] S. H. Hurlbert, "Pseudoreplication and the design of ecological field experiments," Ecological Monographs, vol. 54, pp. 187211, 1984.

[31] M. Plummer, N. Best, K. Cowles, and K. Vines, "coda: output analysis and diagnostics for MCMC," R package version 0.134, 2009.
[32] A. Poole, "The Birds of North America Online," Cornell Laboratory of Ornithology, Ithaca, NY, USA, 2009, http://bna.birds.cornell.edu/BNA/.

[33] M. C. Demchik and W. E. Sharpe, "The effect of soil nutrition, soil acidity and drought on northern red oak (Quercus rubra L.) growth and nutrition on Pennsylvania sites with high and low red oak mortality," Forest Ecology and Management, vol. 136, no. 1-3, pp. 199-207, 2000.

[34] F. R. Magdoff and R. J. Bartlett, "Effects of liming acid soils on potassium availability," Soil Science, vol. 129, pp. 12-14, 1980.

[35] E. Matzner, P. K. Khanna, K. J. Meiwes, and B. Ulrich, "Effects of fertilization and liming on the chemical soil conditions and element distribution in forest soils," Plant and Soil, vol. 87, no. 3, pp. 405-415, 1985.

[36] R. J. Haynes, "Effects of liming on phosphate availability in acid soils," Plant and Soil, vol. 68, no. 3, pp. 289-308, 1982.

[37] B. Côté, I. O’Halloran, W. H. Hendershot, and H. Spankie, "Possible interference of fertilization in the natural recovery of a declining sugar maple stand in southern Quebec," Plant and Soil, vol. 168-169, no. 1, pp. 471-480, 1995.

[38] C. S. Cronan and D. F. Grigal, "Use of calcium/aluminum ratios as indicators of stress in forest ecosystems," Journal of Environmental Quality, vol. 24, no. 2, pp. 209-226, 1995.

[39] R. T. Holmes, J. C. Schultz, and P. Nothnagle, "Bird predation on forest insects: an exclosure experiment," Science, vol. 206, no. 4417, pp. 462-463, 1979.

[40] R. J. Marquis and C. J. Whelan, "Insectivorous birds increase growth of white oak through consumption of leaf-chewing insects," Ecology, vol. 75, no. 7, pp. 2007-2014, 1994.

[41] K. Martin and M. Sommer, "Relationships between land snail assemblage patterns and soil properties in temperate-humid forest ecosystems," Journal of Biogeography, vol. 31, no. 4, pp. 531-545, 2004.

[42] S. E. Pabian, Songbirds and soils: relating forest ecosystem quality to nutrient availability, Ph.D. dissertation, The Pennsylvania State University, University Park, Pa, USA, 2010.

[43] P. J. Kalisz and J. E. Powell, "Effect of calcareous road dust on land snails (Gastropoda: Pulmonata) and millipedes (Diplopoda) in acid forest soils of the Daniel Boone National Forest of Kentucky, USA," Forest Ecology and Management, vol. 186, no. 1-3, pp. 177-183, 2003.

[44] M. F. Wasson, Causes and consequences of calcium limitation in breeding passerine birds, Ph.D. dissertation, Cornell University, Ithaca, NY, USA, 2002.

[45] A. M. Schreffler and W. E. Sharpe, "Effects of lime, fertilizer, and herbicide on forest soil and soil solution chemistry, hardwood regeneration, and hardwood growth following shelterwood harvest," Forest Ecology and Management, vol. 177, no. 1-3, pp. 471-484, 2003.

[46] L. D. Donaldson, Effects of forest liming on foliar chemistry and radial growth of northern red oak and red maple in northcentral Pennsylvania, M.S. thesis, The Pennsylvania State University, University Park, Pa, USA, 2006.

[47] J. R. Sauer, J. E. Hines, J. E. Fallon, K. L. Pardieck, D. J. Ziolkowski Jr., and W. A. Link, "The North American Breeding Bird Survey, Results and Analysis 1966-2009," Version 3.23.2011, USGS Patuxent Wildlife Research Center, Laurel, Md, USA, 2011.

[48] J. Graveland and T. van Gijzen, "Arthropods and seeds are not sufficient as calcium sources for shell formation and skeletal growth in passerines," Ardea, vol. 82, no. 2, pp. 299-314, 1994.

[49] R. Pahl, D. W. Winkler, J. Graveland, and B. W. Batterman, "Songbirds do not create long-term stores of calcium in their legs prior to laying: results from high-resolution radiography," 
Proceedings of the Royal Society B, vol. 264, no. 1379, pp. 239244, 1997.

[50] V. Geissen, J. Illmann, A. Flohr, R. Kahrer, and G. W. Brümmer, "Effects of liming and fertilization on collembola in forest soils in relation to soil chemical parameters," Pedobiologia, vol. 41, no. 1-3, pp. 194-201, 1997.

[51] S. J. Ormerod and S. D. Rundle, "Effects of experimental acidification and liming on terrestrial invertebrates: implications for calcium availability to vertebrates," Environmental Pollution, vol. 103, no. 2-3, pp. 183-191, 1998.

[52] M. C. Fisk, W. R. Kessler, A. Goodale, T. J. Fahey, P. M. Groffman, and C. T. Driscoll, "Landscape variation in microarthropod response to calcium addition in a northern hardwood forest ecosystem," Pedobiologia, vol. 50, no. 1, pp. 69-78, 2006.

[53] M. A. Skeldon, M. A. Vadeboncoeur, S. P. Hamburg, and J. D. Blum, "Terrestrial gastropod responses to an ecosystemlevel calcium manipulation in a northern hardwood forest," Canadian Journal of Zoology, vol. 85, no. 9, pp. 994-1007, 2007.

[54] R. J. Haynes and R. Naidu, "Influence of lime, fertilizer and manure applications on soil organic matter content and soil physical conditions: a review," Nutrient Cycling in Agroecosystems, vol. 51, no. 2, pp. 123-137, 1998.

[55] D. C. Bradley and S. J. Ormerod, "Long-term effects of catchment liming on invertebrates in upland streams," Freshwater Biology, vol. 47, no. 1, pp. 161-171, 2002.

[56] R. A. Haack, "Patterns of forest invertebrates along an acid deposition gradient in the Midwestern United States," in Air Pollution and Multiple Stresses, R. Cox, K. Perey, K. Jensen, and C. Simpson, Eds., pp. 245-257, Canadian Forest ServiceAtlantic Centre, Fredericton, New Brunswick, Canada, 1996.

[57] L. Butler, "Canopy arthropods of an experimentally acidified watershed," in Proceedings of the PA Acidic Deposition Conference: The Effects of Acidic Deposition on Pennsylvania's Forests, W. E. Sharpe and J. R. Drohan, Eds., vol. 1, pp. 107-117, , Environmental Resources Research Institute, The Pennsylvania State University, University Park, Pa, USA, 1999. 

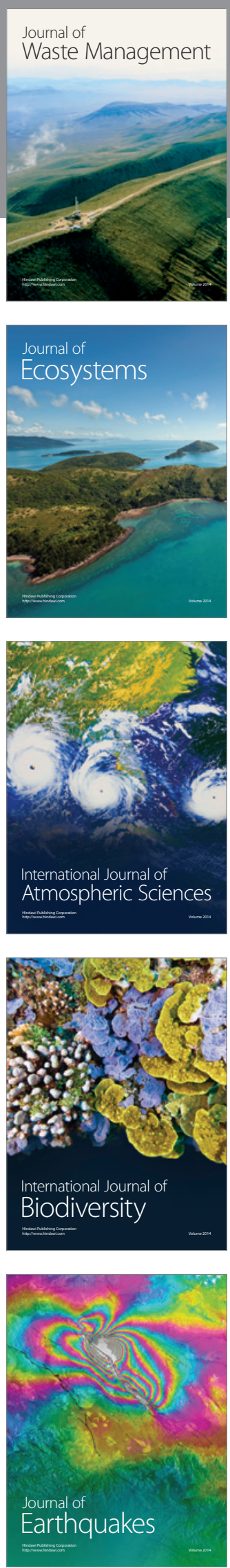
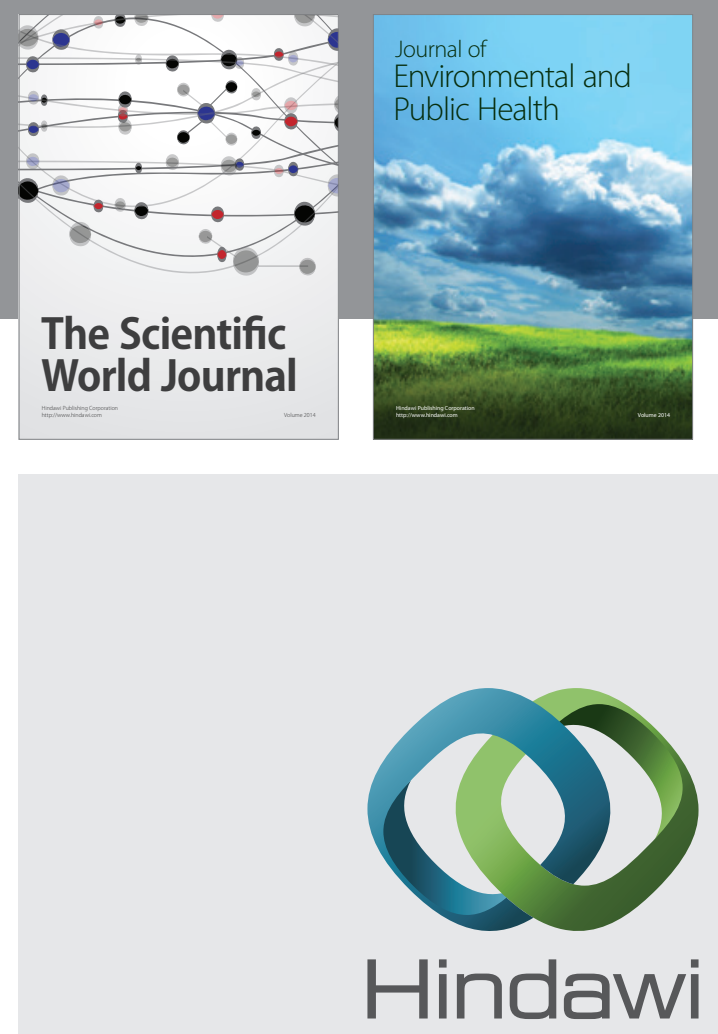

Submit your manuscripts at

http://www.hindawi.com
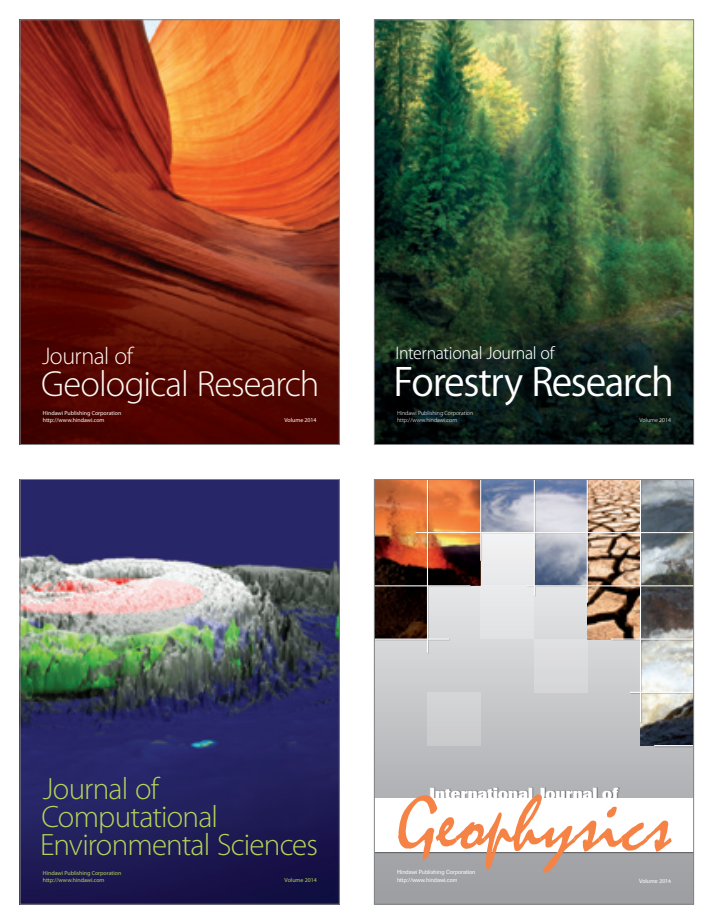
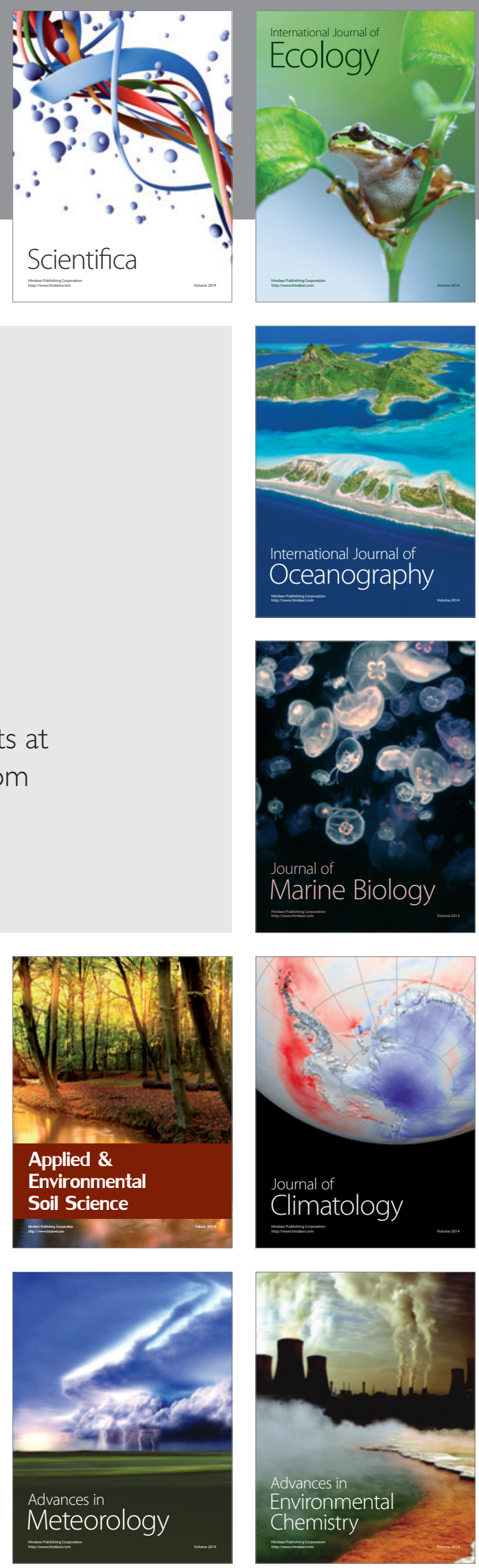